\title{
'THE TSAR WOULD NOT HAVE TAKEN AWAY OUR PENSIONS': COMPENSATION FOR RUSSIAN ARMY FIRST WORLD WAR INVALIDS IN INTERWAR LITHUANIA
}

\author{
Vytautas Jokubauskas \\ (Klaipèda University)
}

\begin{abstract}
This article presents an analysis of the support given to Great War invalids in Lithuania: how did veterans of the Imperial Russian army, injured during the First World War, act in order to procure social security (pensions), and how did Lithuanian legalislation change in reaction to their justified expectations. The social welfare situation of Great War invalids who became citizens of the Republic of Lithuania changed in three different stages: a) the period up to 1926; b) 1926 to 1929; and c) following the passing of a separate law on pensions for former Imperial Russian army war invalids in 1930. It was found that support for these First World War invalids in Lithuania was constantly compared to compensation for those who were injured in the Wars of Independence (1918-1920). The size of pensions for these two groups was never equal. Regardless of the fact that attempts were made to make the two types of pensions equal in 1925-1926, barely six months later, Great War invalids started receiving smaller pensions, until they were eventually suspended altogether before a separate law came into effect in 1930. In the article, the reasons for this are explained as a lack of money and political will, and the view of part of society that those injured in the First World War were 'not fighting for Lithuania'.
\end{abstract}

KEYWORDS: Lithuania; World War I; interwar; pensions; invalids; social care.

After each war, victims and the injuries they experienced are factors that for a long time serve as reminders of past acts of violence." The usual outcomes of war are not just human fatalities,

* The research for this paper was funded by the Research Council of Lithuania (Grant No MIP-021/2015). It is part of the broader project 'Remembrance of the First World War: A Comparative Analysis of Lithuania and East Prussia (before 1939)' implemented at Klaipèda University and headed by Vasilijus Safronovas. 
but also injured soldiers and civilians. ${ }^{1}$ Due to advanced weaponry and medical treatment, the number of people who survived the First World War but remained disabled for the rest of their lives was enormous, reaching into the millions. Some of these people could no longer work, and had a difficult time integrating into peace-time economic activity. Therefore, they required not only material support but physical care as well.

There is no accurate data on how many First World War invalids lived in Lithuania during the interwar years. This is primarily because we do not have any accurate statistics on how many men from Lithuania served in the Imperial Russian army during the Great War. More detailed research on this topic has not yet been conducted. Division General Vincas Vitkauskas once claimed that the figure could reach over 100,000 men. ${ }^{2}$ The historian Algimantas Kasparavičius, who appears to base his claims on certain surviving sources, claims that 'in the summer of 1914-1916, around two or three thousand Lithuanians joined the tsarist army voluntarily, while another 50,000 to 60,000 men from Lithuania were conscripted.' 3 The difference in numbers can be explained in part by the fact that it is not clear what was considered Lithuania during the First World War years. Whatever the case may be, more accurate and reliable figures regarding war invalids does exist. The census held in Lithuania in 1923, apart from various other data, also recorded participants in and victims of the Great War. Once the census data was collated, it was found that within the borders of Lithuania at the time, excluding the Klaipeda region (Territory of Memel), the census data collectors managed to gather information on 64,628 participants in the war. Of these, 11,173 were considered as having died during the war, and 18,712 were injured. Of the latter group, 3,871 were recorded as war invalids. ${ }^{4}$ The criteria on which census data collectors based these people's invalid status remain somewhat

${ }^{1}$ The term invalid is used to describe this group here, for in the interwar period it was used in legislation and in the titles of disabled soldiers' organisations. There is no intention to convey any demeaning implications by the use of this term.

${ }^{2}$ V. Vitkauskas, Raštai (Vilnius, 1988), p. 74.

${ }^{3}$ A. Kasparavičius, 'Didysis karas (1914-1918) ir Lietuva (nereikalingi faktai ir šešèliai istorinèje atmintyje)', Santara, 105/106 (2014), p. 14.

${ }^{4}$ Quantitative data on participants and victims is divided based on districts; 1,375 died in battles, 457 died from injuries, 1,032 died from disease, while 8,309 were listed as missing in action: Lietuvos gyventojai. Pirmojo $1923 \mathrm{~m}$. rugsejo $17 \mathrm{~d}$. visuotinio gyventoju surašymo duomenys (Kaunas, 1923), pp. lxvi, 307. 
unclear. As a result, we can only say that in 1923 there were 53,455 First World War veterans living in Lithuania who had served in the Imperial Russian army (they made up $2.5 \%$ of the population); some had sustained injuries and thus were invalids.

The existence of invalid war veterans was not a new phenomenon, but its scale following the First World War was exceptional. A situation specific to Lithuania also formed because veterans who had been disabled while serving in the imperial armies became a headache for society, whose social and political order had completely changed. In the Republic of Lithuania, whose political and social elite no longer identified with the failed empires, tens of thousands of war veterans appeared who had served the Russian or German empires, along with thousands of invalids who had sustained injuries during the Great War, in which Lithuania did not participate. Just how social integration and support in Lithuania for those men who had served in the German army was organised is a topic for a separate study. ${ }^{5}$ The object of this article is the social welfare laws and practices that applied to Imperial Russian army invalids in Lithuania.

Both the organisation of war invalids and their social welfare under such conditions is a topic worthy of research, for numerous reasons. In this article, it is done within the context of a broader research concept. War invalids are viewed as a specific group, for whom the experience of the First World War was relevant for a longer period than for most of the rest of society. Of all the groups who experienced the war, such as those who lived in Lithuania during the war, refugees and prisoners of war, invalids (along with veterans) were the only ones to systematically seek compensation for their sacrifice. This was why they operated together. An organised and cooperating group, formed on the basis of a specific experience could potentially function as a unique community of memories, becoming bearers of the memory of the Great War. Their cooperation was undoubtedly first of all not provoked by their war experiences as such, or the fact of their disability, but by how Lithuanian governments viewed their disabilities, and the reasons for it. This article seeks to reveal how First World War invalids who had served in the Imperial Russian army strove to reach their goals, social guarantees (pensions)

${ }^{5}$ Cf. V. Safronovas, 'Didžiojo karo sureikšminimo Rytų Prūsijoje ir Klaipėos krašte prielaidos: nuostolių kompensavimo klausimas', Lietuvos istorijos metraštis, 2017/1 (2017), pp. 127-168. 
in Lithuania, and how Lithuanian legislation changed in response to their justifiable expectations and the specific welfare practices that applied to those who had been injured during the war. During the research, it became clear that the entire dynamics of the phenomenon fit into three periods, which will be analysed further in separate parts of this article: 1) up to 1926; 2) 1926 to 1929; 3) after 1930, when a separate law was passed in Lithuania outlining the support to be offered to Great War invalids from the Russian army.

I would like to mention the novelty of this research. The situation of Great War invalids from the Russian army in the Baltic States after 1918 is not a new topic. ${ }^{6}$ However, in Lithuania it has so far not been the focus of broader analysis. ${ }^{7}$ Aušra Jurevičiūtè, a historian at the Vytautas the Great War Museum in Kaunas, has come closest to analysing this issue. In analysing in detail the war veterans organisations that functioned in interwar Lithuania, and the social welfare issues faced by First World War veterans, she touched slightly on the subject of this article. However, Great War veterans who suffered injuries in the war, and their efforts in fighting for compensation, were not a separate object of her research. ${ }^{8}$ Neither did she look at how and why laws on providing support for Great War veterans changed in Lithuania. This is why this article is the first such attempt in Lithuanian historiography to take a closer look at these questions.

\section{The 1920s: the first Lithuanian pensions for Great War invalids}

The practice of providing compensation to soldiers for disabilities incurred during their service which made them incapable of working was not only known in Lithuania, but started relatively early. The

${ }^{6}$ Cf. L. Esse, 'Nii oleme 20 aastat sunnitud olnud kiratsema omariikluse juures...' Esimese maailmasõja invaliidide toetused ja ühiskondlik positsioon 1920.-1930. aastate Eestis', ed. T. Tannberg, Esimene maailmasõda ja Eesti, II (Tartu, 2016), pp. 507-533.

${ }^{7}$ Cf. V. Safronovas, 'Pirmojo pasaulinio karo atminimas Lietuvoje ir Rytų Prūsijoje: naujų tyrimų pradžia', Lituanistica, vol. 61(3) (2015), pp. 149-159.

${ }^{8}$ A. Jurevičiūtè, 'Lietuvos kariuomenès kūrejų savanorių sajungos kūrimas', Karo archyvas, vol. XVI (2000), pp. 137-145; eadem, 'Karo invalidų organizacijos Lietuvoje 1923-1940 m.', Kauno istorijos metraštis, vol. VIII (2007), pp. 7-54; eadem, 'Kariuomenès pirmūnų sajungos ịkūrimas veikla 1937-1940 metais', Lietuvos istorijos studijos, 19 (2007), pp. 80-99; eadem, Buvusiu kariu organizacijos ir ju vaidmuo Lietuvos vidaus politikoje 1923-1940 m.. PhD thesis (Kaunas, 2009). 
first law on benefits for disabled Lithuanian army soldiers was passed in May 1919. ${ }^{9}$ Three years later, in 1922, a more detailed act was passed which regulated the procedure for the payment of benefits. However, according to this law, the only soldiers to receive pensions and one-off benefits were 'a) Lithuanian army war invalids and in the event of their death, their families; $b$ ) the families of deceased soldiers if they died or were declared missing without trace from service in the Lithuanian army; and c) members of the Lithuanian Riflemen's Union, if they served as soldiers and comply with points a) and b) in this paragraph'. According to this law, war invalids were considered as only those individuals who had lost 'the capability to work or their health' during service in the Lithuanian army. ${ }^{10}$ In other words, according to these acts, First World War invalids would not be eligible for pensions. The calculation of all soldiers' pensions was also based exclusively on their term of service accrued with the army of the Republic of Lithuania. ${ }^{11}$ One example suffices to give an impression of how soldiers who were crippled in the Great War must have felt. In October 1924, a Great War invalid wrote to the press, asking: "When serving with the Russian army, in February 1915, I was injured and spent the remainder of the time in Russian hospitals. Returning to Lithuania in 1922, I spent my time at home until July of this year, and have been in hospital ever since then. On 26 September, the Special Commission for Health Checks acknowledged my injury sustained in the army, and that it has made me $100 \%$ incapable of working. What amount of pension can I receive on these grounds?' The response published in a professional soldiers' magazine was laconic and clear: 'According to the current pensions law, announced in 'Army Orders' No. 71 of 1923, only Lithuanian army war invalids are eligible for a pension.' ${ }^{12}$

Jurevičiūte has claimed that the Lithuanian government did not allocate funds for First World War invalids until 1930. ${ }^{13}$ Later she refuted her claim, indicating that in the second half of the 1920s

9 'I statymas apie algas ir pašalpas kariškiams ir jų šeimynoms', Vyriausybès žinios, 7 (1919), p. 7.

10 'Netekusiems sveikatos kariams, jų šeimoms o taip pat žuvusiujų karių šeimoms pensijų įstatymas', Vyriausybès žinios, 104 (1922), p. 6.

11 'Iš „Isakymų Kariuomenei“: Pensijos kariams ir žuvusiujjų karių šeimoms', Karys, 19 (207) (1923), p. 228.

12 'Klausimai ir atsakymai', Karys, 43 (283) (1924), p. 356.

${ }^{13}$ A. Jurevičiūtè, Buvusių karių organizacijos, p. 114. 
in Lithuania, 201 First World War invalids did nevertheless receive pensions. ${ }^{14}$ The fact that a small portion of these invalids did receive pensions, albeit of differing amounts, is confirmed in interwar publications. ${ }^{15}$ So, some changes were made in the provision of benefits for Russian army invalids in Lithuania; however, achieving these changes was fraught with complications.

The (until 1924 Temporary) Committee for War Invalids was established in 1921 to handle all matters concerning war invalids. Headed by Lieutenant General Vladas Nagevičius, the organisation saw its prototype in the Alexander Committee that had functioned in the Russian Empire until 1918, and sought to provide support not just for Lithuanian army invalids but Great War invalids in Lithuania as well. However, the committee's main activity was the registration of war invalids, making a record of their degree of disability, to set up companies where the disabled could find work, to procure orthopedic equipment, etc. In addition, the committee had to fund almost all of its activities from public donations, as the government only started to provide it with regular funding from $1927 .{ }^{16}$ One explanation for this delayed funding could have been that for a long time it was not known how many Great War invalids there were in Lithuania who needed support. They did not rush to register with the committee, as it could not offer disabled pensions.

Conditions prompting changes to this situation included the new Law on Soldiers' Pensions, which the Lithuanian government finished drafting on 10 December 1924, after which it was sent for deliberation to the Seimas. ${ }^{17}$ According to the law, pensions were to be paid to 'soldiers of poor health, their families and the families of soldiers who had died during the war'. During the parliamentary discussions of the law, the issue of those who had incurred serious injuries in the Great War was specifically debated. During one discussion on 28 April 1925, the issue was raised by Petras Jočys, a war refugee. All we know about his military experience is that he spent the war in the depths of Russia, in Voronezh. This member of the Lithuanian Labour Federation, who had 15 mandates in the II Seimas, asked:

${ }^{14}$ A. Jurevičiūtè, 'Karo invalidų organizacijos Lietuvoje 1923-1940 m.', p. 13.

${ }^{15}$ J. Katinskas, 'Tarnavusių rusų kariuomeneje invalidų pensijos', Lietuvos karo invalidas, 1 (1930), p. 23.

${ }^{16}$ Bukevičius, 'Karo invalidams šelpti komiteto dešimties metų veikimo apžvalga (1921-1931 m.)', Mūsu žinynas, vol. XXI, 80 (1931), pp. 410-413.

17 'Karių pensijos įstatymo projektas', Karys, 1 (293) (1925), p. 6. 
We would be curious to find out whether the new law up for deliberation will include only Lithuanian army invalids, or will it include Great War invalids as well. It would be very wrong to continue viewing Great War invalids in the same way as they have been viewed in the past. Our fraction believes that the establishment of the Lithuanian state is the fruit of that war, and as such, thanks to those Great War casualties, our country became independent [...] Great War invalids should be covered by the pensions law, because their contribution towards the creation of our independent state, albeit smaller than others, does nonetheless exist. ${ }^{18}$

Jočys also made a reference to social welfare arguments, ${ }^{19}$ and new arguments were put once the issue was discussed again a few months later. On 23 June, during the subsequent deliberation of the law, another member of the Farmers' Union, Eliziejus Draugelis, spoke in favour of providing welfare support to all war invalids and their families living in Lithuania. The military doctor, who had been conscripted into the Russian army in 1914, urged members of parliament not to look upon Russo-Japanese and First World War war invalids differently. The number of individuals in Lithuania who had become incapable of working following their service in various armies and who needed social welfare, according to him, was around 10,000 to 14,000 , or even more. Draugelis nevertheless recommended providing pensions to Lithuanian army soldiers, and that soldiers from other armies be covered by separate laws. Colonel Teodoras Daukantas, the minister of defence, another First World War veteran, also spoke on granting welfare to Russian army invalids during these debates. He agreed that war invalids who had served in the armies of other countries could not be prioritised over Lithuanian army invalids. At the same time, the idea of pensions for German army war invalids in the Klaipeda region was also raised. ${ }^{20}$ So, according to the minister, Russian army invalids would be the only ones left without any form of support. Daukantas stated clearly that support for them should not depend on the fact that they had not served in the Lithuanian army, as they were still 'our Lithuanians'. However, it is obvious that the minister's enthusiasm for this matter was encouraged by inaccurate data provided by the Invalids Committee

18 178th meeting, 28 April 1925, Seimo stenogramos, pp. 12-13.

${ }^{19}$ Ibid.

${ }^{20}$ On 27 October 1924, the first meeting for the transfer of rights in the Klaipeda region was held as part of the Lithuanian-German conference in the German Ministry of Foreign Affairs. During the meeting, five sub-commissions were created, one of which was delegated to handle pensions: 'Lietuvių Vokiečių konferencija', Karys, 45 (285) (1924), p. 371. 
about the specific group at the centre of attention. Those who had registered in order to receive support composed of only 114 Russian army war invalids in 1925, whose pensions would have amounted to 99,432 litas. ${ }^{21}$ These arguments were eventually supplemented by Sikstas Riauka, a member of the Christian Democrats, who could speak on behalf of Russian army war invalids (he lost his right arm in the war in 1914). His reaction to the recommendation from the Parliament Legal Commission to apply the Law on Soldiers' Pensions only to Lithuanian army invalids was to call it 'a provocation':

When those soldiers served the Russian army and other armies, we did not yet have independence, so those soldiers cannot be placed in an exclusive position [...] were the Russian tsar still in power, he would not take away our pensions, and now we, the unhappy sons of Lithuania, whose homeland was ripped into pieces, are being rejected by that Lithuanian government. That is why this recommendation would make those people look unfavourably upon the Lithuanian state, and so I cannot call it anything but a provocation. ${ }^{22}$

These arguments were enough for the Legal Commission to reject the amendment. This can also be explained by the fact that the number of First World War veterans in the II Seimas of the Republic of Lithuania ${ }^{23}$ outnumbered Draugelis and Riauka. In addition, war refugees who had spent the Great War in the depths of Russia could also have stood in solidarity with the veterans: there were at least 29 such members of parliament. What we notice is that the percentage of war veterans and former war refugees who were among the members of the II Seimas was much greater than the percentage of this group in Lithuanian society. Perhaps that is why the legalisation of concessions or social welfare for First World War invalids did not meet any obstacles in the legislative process.

According to the new law, Great War invalids still basically had little chance of receiving a soldier's pension for their time spent serving in the army: the law outlined that the period up to $16 \mathrm{Fe}-$ bruary 1918 spent serving another country's army, if earlier they had occupied actual Lithuanian territory, would be included only in cases where the individual had afterwards served for at least five

${ }^{21}$ Minister of Defence Colonel Daukantas, 194th parliamentary session, 1925. Lietuvos valstybès centrinis archyvas (henceforth - LCVA), f. 929, ap. 1, b, 467, 1. 91.

22 194th parliamentary session, 23 June 1925, Seimo stenogramos, pp. 5-6.

${ }^{23}$ The following members of parliament were First World War veterans: Jonas Staugaitis, Ladas Natkevičius, Aleksandras Tornau, Balys Žygelis, Leonas Bistras, Jonas Steponavičius, Feliksas Miškinis, Tadas Aleliūnas, Jurgis Daukšys, Augustas Rogalis, Jokūbas Robinzonas, etc. 
years in the Lithuanian army. However, there were provisions for being eligible for an invalid's pension: in most cases, this pension would consist of the same percentage of a soldier's or officer's last monthly salary as the percentage of their lost capability to work. If an individual had become $100 \%$ incapable of working, they could expect an added supplement of 50\%: supplements also went to people who had become invalids whilst serving beyond their mandatory service period. ${ }^{24}$

The passing of this law did not yet resolve the problem completely. Even though war invalids, and in the event of their death, their families, had the right to a pension according to the law, when the Seimas crossed out the words 'Lithuanian army', it did not specify exactly invalids of which countries' armies the law would apply to. The preliminary version of the document contained the clear formulation that pensions would be paid to soldiers who were 'war invalids of the Lithuanian and Russian armies'. ${ }^{25}$ But this was eliminated from the final draft, and the remainder of the law, except for this point, basically concentrated on Lithuanian army soldiers' pensions. This created space for the expression of much doubt, not just in the press, where questions were raised as to whether pensions should be provided only to war invalids from the Lithuanian army, or to Russian and German army invalids as well. ${ }^{26}$ The question of whether the law applied to Lithuanian citizens who had become war invalids whilst not serving in the Lithuanian army arose again on 1 October 1925, when a commission formed by the Executive Headquarters for preparing rules for the law's implementation met (chaired by Lieutenant General Jonas Kubilius, with Colonel Konstantinas Šalkauskas and Lieutenant Colonel Jurgis Bobelis as members, and Captain Andrius Pridotkas as secretary).

The commission expressed the opinion that 'the law would apply to all invalids, as those points that affect only those who served in the Lithuanian army are marked in the law. ${ }^{27}$ However, the executive rules announced on 15 January 1926 stated that: 'The law applies to all soldiers of Lithuania, ${ }^{28}$ thus leaving some uncertainty whether First World War invalids were also included. The chair

\footnotetext{
24 'Karių pensijų įstatymas', Vyriausybès žinios, 201 (1925), pp. 1-2 (§§ 4-6, 14, 18).

${ }^{25}$ 178th session, 28 April 1925, Seimo stenogramos, p. 13.

${ }^{26}$ [J.] Byla, 'Karių pensijų įstatymas', Kardas, 16 (1925), p. 2.

${ }^{27}$ Protocol, 1 October 1925, LCVA, f. 384, ap. 5, b. 2, 1. 175.

28 'Karių pensijų įstatymui vykdyti taisyklès', Vyriausybès žinios, 213 (1926), p. 3.
} 
of the Lithuanian War Invalids Union appealed to the minister of defence regarding this matter on 18 January 1926. In his note, he reminded the minister of how members of parliament had given their assurance that 'The passed law includes all war invalids.' According to the chair, the Ministry of Defence 'understood the law's boundaries too narrowly, and for that reason First World War invalids, as per the rules, were accidentally not counted among the number of pension recipients' ${ }^{29}$ The ministry was quick to respond to the War Invalids Union: ${ }^{30}$ the note from the minister, Leonas Bistras, indeed states: 'It is not clear from the [formulation in the] law whether it can apply to First World War invalids [while] his legislative consultants believe that it cannot. The matter must still be deliberated. ${ }^{31}$

When discussing the law's executive rules, the commission of legislative consultants did not recognise Russian army invalids as eligible for these pensions. ${ }^{32}$ The chair of the Committee for War Invalids, Lieutenant General Vladas Nagevičius, tried to pressure the ministry. In his report to it, he wrote that First World War invalids tried appealing to the Embassy of the Soviet Union, which had allegedly assured them that 'Soviet Russia had given Lithuania three million gold roubles for supporting former Great War invalids.' According to the general, this response from the Soviets had 'completely convinced war invalids'. That is why the influential General Nagevičius recommended: in protecting the authority of the Lithuanian state, it is necessary to immediately correct legal acts regarding the pensions of First World War Russian army invalids. ${ }^{33}$ At the time, the committee had calculated that the pensions for 227 Russian army invalids would require 218,760 litas, while one-off benefits would require 58,968 litas of state funds. ${ }^{34}$ When even this did not help, on 12 February the Lithuanian War Invalids Union complained

${ }^{29}$ Note from the Lithuanian War Invalids Union dated 18 January 1926 to the Ministry of Defence (MOD), LCVA, f. 384, ap. 5, b. 2, 1. 7.

${ }^{30}$ Note from the Executive Headquarters dated 27 January 1926 to the chairman of the Lithuanian War Invalids Union, ibid., 1. 9.

${ }^{31}$ Note from the Executive Headquarters dated 26 January 1926 to the chairman of the Committee for War Invalids, ibid., 1. 8.

${ }^{32}$ Note from the minister of defence dated 27 December 1926 to the Parliamentary Commission for Complaints and Petitions, ibid., 1. 167v.

${ }^{33}$ Report from the chairman of the Committee for War Invalids to the MOD, ibid., 1. 17.

${ }^{34}$ News about Russian army invalids, 9 February 1926, ibid., 1. 15. 
to the Seimas. The complaint outlined that in their discussions and by passing the law, members of parliament had decided to allocate pensions to Russian army First World War invalids, but based on the ministry's rules, they refused to execute this law. Officials were accused of 'understanding the law's boundaries too narrowly', and thus in its complaint, the War Invalids Union asked the Parliament 'to stand in defence of war invalids being wronged on the pensions issue'. ${ }^{35}$ The Executive Headquarters confirmed the necessity of appealing to the Seimas, responding to the Committee and the War Invalids Union on 26 February that, based on the latest version of the law, pensions could not be paid to First World War invalids, and that the Seimas had to return to this matter. ${ }^{36}$ On 22 March, the Parliamentary Commission for Complaints and Petitions appealed to the ministry to find out the rules regarding the resolution of the pension payment issue. ${ }^{37}$ In the end, the Parliament's official intervention was not required, as on 17 March the Lithuanian government, and on 18 March the Parliamentary Defence Commission, decided that pensions would be allocated not only to war invalids from the Lithuanian army, but to those from other armies as well, 'whose health had suffered in other wars, the Great War specifically, and others'. ${ }^{38}$ So, on 22 March, the Executive Headquarters informed the chair of the commission responsible for preparing the rules for the execution of the Law on Soldiers' Pensions that on 17 March the government had decided to provide all army invalids who were citizens of Lithuania with pensions. ${ }^{39}$

After a good month of trying to find an explanation, the Utena District Conscription Commission appealed to the Executive Head quarters. The commission also reiterated that the law 'did not outline that Lithuanian citizens who had served in the Russian army would receive pensions', alleging only that 'the resolution of the Cabinet

${ }^{35}$ Complaint from the board of the Lithuanian War Invalids Union, dated 12 February 1926, to the Parliamentary Commission for Complaints and Petitions, ibid., 1. 18.

${ }^{36}$ Note from the Executive Headquarters, dated 26 February1926, to the chairman of the Committee for War Invalids, ibid., 1. 20-21.

${ }^{37}$ Note from the Parliamentary Commission for Complaints and Petitions, dated 22 March 1926, to the MOD, ibid., 1. 29.

38 'Lietuvos gyvenimas. Vyriausybès darbai', Karys, 14-15 (358-359) (1926), p. 120 .

${ }^{39}$ Note from the Executive Headquarters dated 22 March 1926, LCVA, f. 384, ap. 5 , b. $2,1.31$. 
of Ministers was printed in the press that Russian invalids would also receive a pension.' There was no explicit instruction for the procedure of allocating pensions to Russian army war invalids. ${ }^{40}$ In its response, the Executive Headquarters confirmed the validity of the government resolution, and indicated that new rules for the law's implementation would be prepared in the near future. ${ }^{41}$ Ultimately, while the rules were being prepared, a precise formula was conceived that was to eliminate any misunderstandings. Vincas Mašalaitis, the secretary of the Council of Ministers, might have played a role here. When considering the rules, he expressed doubts over whether the sentence 'invalids, Lithuanian citizens, of armies from all states receive a pension' meant that even those citizens who had served in the French army but became invalids in Morocco were eligible for a pension, or those who fought against the Lithuanian government by serving for the Red Army, etc. ${ }^{42}$

Amended rules for the implementation of the Law on Soldiers' Pensions were announced on 9 June 1926. They indicated that the law would apply to 'Russian army' war invalids who were Lithuanian citizens, and whose disabilities had been incurred before 16 February 1918. It was foreseen that individuals who submitted documents to receive a pension before 1 January 1927 would receive it from 1 January 1926, while those who submitted their documents later would receive pensions from the date of allocation. ${ }^{43}$ In this way, the ambiguity over the wording of the law was regulated. The mention of specific dates and countries (Russia) was to ensure that individuals who had served in third countries and had become war invalids would not receive pensions, and neither would those who had fought against the Lithuanian state. So, the discussions in 1925-1926 amounted to producing specific results: legal regulations were put in place in Lithuania so that First World War invalids who had served in the Russian army would receive the same pensions

${ }^{40}$ Note from the Utena District Conscription Commission dated 22 April 1926, ibid., 1. 45.

${ }^{41}$ Note from the Executive Headquarters, dated 27 April 1926, to the head of the Utena district, ibid., 1. 47.

${ }^{42}$ Note from the secretary of the Cabinet of Ministers, dated 22 May 1926, to the prime minister, ibid., 1. 85.

43 'Karių pensijų ịstatymui vykdyti taisyklių pataisymai', Vyriausybès žinios, 228 (1926), p. 4. 
as those paid to Lithuanian army war invalids, many of whom had become invalids during the Wars of Independence of 1918 to 1920.

\section{'Russian war invalids': a battle (not) lost?}

Once the law acknowledged that Lithuanian citizens who had served in the Imperial Russian army during the Great War deserved war invalid pensions from the Republic of Lithuania, a new problem arose. The actual payment of invalids' pensions to all those who had submitted applications started to be seen as a burden that was too great for the state to bear. There were good grounds for this: the number of individuals who applied for such pensions was now much more than the few hundred that were envisaged when the law was being considered. As the minister of defence, Lieutenant Colonel Antanas Merkys, admitted in the official response to the Seimas, until 15 October 1926, pensions had been granted to 54 invalids from the Russian army. Then the pension allocation was stopped, because it became apparent that around 1,500 to 2,000 requests were pending, and the ministry did not have the available funds: in order to provide the pensions (100 to 150 litas each), around three million litas was needed. Thus, on 24 November, the government was advised to 'refrain, as far as possible' from paying out pensions to First World War invalids. ${ }^{44}$

These kinds of decisions by the ministry naturally resulted in a wave of complaints. After the law was passed in August 1925, for the remainder of 1926, the public became accustomed to the fact that pensions would go to all war invalids, including those who had been injured during the Great War. For example, the Lithuanian Riflemen's Union weekly Trimitas made a short announcement on this subject in March $1926 .{ }^{45}$ Afterwards, the editorial board directed all those who wrote to the magazine asking 'Can I get a pension if my health suffered during the Great War?' to the message. ${ }^{46}$ This created the impression that the government's provisions were actually intentional. However, I believe that there was no

${ }^{44}$ Note from the minister of defence, dated 27 December 1926, to the Parliamentary Commission for Complaints and Petitions, LCVA, f. 384, ap. 5, b. $2,167 \mathrm{v}$.

45 'Duos pensijas visiems invalidams', Trimitas, 12 (1926), p. 356.

46 'Klausimai ir atsakymai', Trimitas, 14 (1926), p. 472; 'Klausimai ir atsakymai', Trimitas, 22 (1926), p. 728. 
mention of stopping the implementation of the law. Even though the decision to stop granting pensions to those injured during the Great War while serving in the Russian army was made prior to the coup of 17 December 1926, the law's implementation was felt afterwards. This is why the pressure on the government to renew payment was transformed into increasing agitation in the general community towards the new government that took control following the overthrow. ${ }^{47}$ At least these were the kinds of arguments used by Lieutenant General Nagevičius when appealing to the Ministry of Defence to solve the matter. ${ }^{48}$

The ministry rushed to find a solution, as it had already received over a thousand requests for pensions from Great War invalids, as well as numerous complaints over the delay in their payment. On 19 April 1927, the Ministry of Defence appealed to the government with a request to consider immediately the question of First World War invalid pensions, submitting a newly drafted law. ${ }^{49}$ In it, war invalids were divided into two groups (officers and soldiers), and five categories, foreseeing pensions ranging from 25 to 180 litas: ${ }^{50}$ 50-180 litas for officers, and 25-90 litas for the ranks. ${ }^{51}$ Not only was the ministry afraid that in 1928 it would have to fund two years of pensions due to the backlog of requests, ${ }^{52}$ but it also took the position that the draft law should be backdated, 'to eliminate the possibility that Russian war invalids' might claim war invalid pensions that they were eligible for based on the law of 1925 . Instead, recommendations were made to pay pensions that were half of those given to war invalids from the Lithuanian army. There were two main arguments for this. First, it was alleged that the Imperial Russian government had paid pensions of 36 roubles (or 1.5 US dollars), so that even half the smallest Lithuanian war invalid pension only amounted to 22 litas per month (or 2.2 US dollars), that is, one and a half times more than the Russian Empire

${ }^{47}$ Report by the head of affairs of the Committee for War Invalids dated 15 March 1927, LCVA, f. 384, ap. 5, b. 3, 1. 3.

${ }^{48}$ Report by the chairman of the Committee for War Invalids dated 31 March 1927, ibid., 1. 4.

${ }^{49}$ Note from the MOD dated 19 April 1927 to the prime minister, ibid., 1. 6.

50 'Lietuvos gyvenimas. Ministerių Kabinetas', Karys, 18 (414) (1927), p. 170.

${ }^{51}$ Draft of the law on pensions for war invalids who served in the Russian army (1927), LCVA, f. 384, ap. 5, b. 3, 1. 10-11v.

${ }^{52}$ Note from the MOD dated 12 August 1927 to the prime minister, ibid., 1. 12. 
had paid. These calculations, incidentally, were far from realistic. ${ }^{53}$ Secondly, the ministry argued that when the law was being discussed in the Parliament, the number of Russian army Great War invalids given was incorrect. In addition to the alleged 54 individuals who had been allocated pensions in the autumn of 1926, by November the ministry had received 546 unprocessed requests. According to data from the Committee for War Invalids, it provided support to around 700 First World War invalids, while the total number of such individuals in Lithuania was around 1,500. So, it was five times more than the number mentioned in the Seimas when the law was being discussed, and five to eight times more than the number of Lithuanian army war invalids. ${ }^{54}$ Indeed, the number of war invalids had not been suitably calculated during parliamentary debates: in 1925, the operating data mentioned 39 Lithuanian army officers, 148 ordinary soldiers, and 145 Russian army war invalids; while when the 1928 budget was being prepared, it was calculated that 1,271 individuals would need pensions (of whom 819 were Russian army war invalids), amounting to a total of 1,378,741 litas per year. ${ }^{55} \mathrm{As}$ of 1 April 1927, the ministry had received 901 requests for pensions from First World War invalids. According to its calculations, if it were to pay out the pensions in line with the law of 1925 , it would need 705,852 litas per year. But if the ministry's 1927 recommendations were to apply, that sum could be reduced to 322,080 litas, and according to the government's last draft law, to 352,308 litas. ${ }^{56}$

In this way, the argument of a lack of money became the main factor determining why the implementation of the law passed in 1925 was stalled. Allegedly, it was impossible to provide Russian army Great War invalids with pensions of the same size as Lithuanian army war invalids for precisely that reason. The allocation of new pensions for Russian army Great War invalids was suspended from 1 July 1927, while those who had already been granted pensions received

${ }^{53}$ The Imperial Russian rouble and US dollar exchange rate, based on which pensions were calculated arguing for the need to reduce them in Lithuania, was very inaccurate. In 1913, one US dollar cost 1.94 roubles, based on the gold standard.

${ }^{54}$ Explanation for the amendment to the Law on Soldiers' Pensions, LCVA, f. 384 , ap. 5 , b. $3,1.17-18$ apv. 1.

${ }^{55}$ Report by the head of the Pensions Branch in the Line-Officers Department of the Executive Headquarters for October 1927, ibid., 1. 36-38v.

${ }^{56}$ Information about Russian army invalid requests for pensions and the sum they should be paid, dated 1 April 1927, ibid., 1. 21. 
a significantly lower sum. The pensions dropped from 48-273 litas (an average of 130.24 litas) to 25-90 litas (51.85 litas), or more than half their earlier amount. As a result, costs for paying Russian army Great War invalid pensions were reduced from 7,033 litas to 2,800 litas per month (or from 84,396 litas a year to 33,600 litas). ${ }^{57} \mathrm{In}$ addition, another 35 war invalids received temporary pensions, so in all they were paid out to just 89 individuals, requiring 106,116 litas in costs a year. ${ }^{58}$

The fact that with its resolution, the government could basically block the implementation of the law passed by the Seimas became possible due to the general political situation in Lithuania. Following the coup of 17 December 1926, the Parliament still functioned for a while, before being dissolved on 12 April 1927. This removed the possibility of representing the interests of Russian army Great War invalids by democratic means. The only way to change the situation was to influence the government and its separate members. So when the president, Antanas Smetona, travelled around rural areas in Lithuania, First World War invalids would constantly make their requests known, and complained about their pensions. ${ }^{59}$

But as long as the government was headed by Augustinas Voldemaras, who had become prime minister after the coup, it was obviously more interested in further tightening the belt on the subject of Russian army war invalids. For example, on 12 August 1927, during his first days in office, Colonel Daukantas, who had been appointed minister of defence for a third time, suggested introducing a separate law to solve the issue of Russian army war invalid pensions. ${ }^{60}$ Over the course of a few days, on 16 August, after its first reading, the government accepted the draft law on war invalids who had served in the Russian army. However, pension sizes were only reduced further ${ }^{61}$

${ }^{57}$ List of Russian army invalids who received pensions as per the new rules for the implementation of the Law on Soldiers' Pensions (Vyriausybès žinios, 228 (1926) line 1485) that are equal to Lithuanian army invalid pensions, and whose current pensions would be suspended from 1 July 1927 due to a lack of funds, and who would be allocated with new temporary pensions, ibid., 1. 1-2.

${ }^{58}$ Information about Russian army invalid pension recipients (1927), ibid., 1. 5.

${ }^{59}$ Note from the MOD dated 6 October 1927 to the prime minister, ibid., 1. 31.

${ }^{60}$ Note from the MOD dated 12 August 1927 to the prime minister, LCVA, f. 384 , ap. 5 , b. $4,1.121$.

${ }^{61}$ Note from the head of affairs of the Cabinet of Ministers dated 23 January 1928 to the MOD, ibid., 1. 4. 
compared to the ministry's draft. ${ }^{62}$ The ministry, meanwhile, believed that Lithuanian and Russian army war invalid pensions should not be the same. The same arguments arose, that these pensions weighed too heavily on the state budget, as there were significantly more Russian army war invalids than Lithuanian army invalids. However, internal government documents clearly identified another reason:

It would not be completely just to measure equally Russian war invalids who fought for foreign interests, sometimes even going against our Nation's interests, and Lithuanian war invalids who sacrificed their health in struggles to regain the Nation's independence. We should view the granting of pensions to Russian war invalids firstly as a matter of social welfare, and the granting of pensions to Lithuanian war invalids as both social welfare and as the Nation's recompense for their health lost in the course of taking back our independence. ${ }^{63}$

The ministry rushed to pass the new law, appealing again to the government on 6 October 1927. It asked the government to pass the draft law that it had already approved following the first reading. There were reasons for this rush, for in a legal sense, the ministry's actions were very questionable: it had de facto already acted according to its recommendation, which had not yet received the final approval of the government; whereas the law of 1925 was not being implemented, resulting in numerous letters of request and complaint from citizens. However, lacking a firm legal basis, the ministry could not give them a response. A curious situation started to emerge as 1928 approached: 114 Russian army war invalids were to receive pensions from the ministry, but they were to be paid out based on three different procedures, and would have been very different amounts; 54 individuals would have received the same sum as Lithuanian army war invalids, 21 would have received pensions according to the government's reductions, and 39 would have received pensions based on the draft law prepared by the ministry and approved by the government only after the first reading. Given this situation, the minister of defence was prepared to state that, as of 1 January 1928, all 114 individuals would receive reduced pensions ... based on the new, as yet unconfirmed, law. ${ }^{64}$ Understandably, the minister clearly believed that this kind of decision was not legitimate. This

${ }^{62}$ Draft of the law on pensions for Russian army war invalids (1927), LCVA, f. 384 , ap. 5 , b. $3,1.10-11$ v.

${ }^{63}$ Note on amendments and additional explanations regarding the Law on Soldiers' Pensions, LCVA, f. 384, ap. 5, b. 4, 1. 18.

${ }^{64}$ MOD resolution, January 1928, ibid., 1. 44. 
explains why on 13 January $1928,{ }^{65}$ and again after a few weeks, on 2 February, the ministry again appealed to the prime minister, urging the government to pass the law prepared by the ministry on its second and third readings. ${ }^{66}$ The draft was finally set to be debated on 13 March. ${ }^{67}$ The press did not delay announcing that the Lithuanian government was getting ready to discuss the draft of the 'Law on Pensions for Lithuanian Citizens who Served in the Russian Army', according to which officers would receive pensions ranging from 50 to 180 litas, and ordinary soldiers from 25 to 50 litas per month. ${ }^{68}$

However, the situation took an unexpected turn at the government level. At the time, the Ministry of Internal Affairs was preparing a new social welfare law, and plans were being made to provide for Russian army Great War invalids within its framework. So, on 10 August 1928, the government decided to hand the matter of providing pensions for these invalids over to the Ministry of Internal Affairs, although the Ministry of Defence had to continue paying the pensions that had been granted up until then. ${ }^{69}$ Indeed, the Ministry of Internal Affairs received the personal files of 981 First World War invalids and lists of their names. ${ }^{70}$ Despite this, already in 1930, it was stated that the drafting of the Law on Social Welfare would take longer than expected, and it was not correct to identify war invalids as potential social welfare recipients, or to create sections in the Ministry of Internal Affairs to handle their administration that would merely duplicate the activities of the Ministry of Defence. So, after two years, it was decided that the allocation and payment of Russian army Great War invalid pensions would again all be looked after by the Ministry of Defence. ${ }^{71}$ On 2 May 1930, the files with requests for pensions from Russian army war invalids were returned

${ }^{65}$ Note from the MOD dated 13 January 1928 to the prime minister, ibid., 1. 1.

${ }^{66}$ Note from the MOD dated 2 February 1928 to the prime minister, ibid., 1. 62.

${ }^{67}$ Note from the Cabinet of Ministers dated 12 March 1928 to the MOD, ibid., 1. 65 .

68 'Pensijos tarnavusiems rusų kariuomenèj', in: Trimitas, 11 (1928), p. 356.

${ }^{69}$ Note from the secretary of the Cabinet of Ministers dated 17 August 1928, LCVA, f. 384 , ap. 5 , b. $5,1.1$.

${ }^{70}$ List of unresolved personal files of individuals requesting pensions as Russian army invalids that was sent to the Ministry of Internal Affairs, 21 September 1928, ibid., 1. 152-167.

${ }^{71}$ Protocol, 28 January 1930, LCVA, f. 384, ap. 5, b. 11, 1. 43-45. 
to the Ministry of Defence. ${ }^{72}$ From this date, the ministry managed the matter for nine years, until, in order to save on costs, from 1 September 1939, the administration and payment of all soldiers' pensions was transferred to the Pensions and Benefits Department of the Ministry of Finance. ${ }^{73}$

Deliberations and attempts to pass a new law aimed specifically at Russian army Great War invalids lasted for three years, while Augustinas Voldemaras headed the government, and never ended. The final decisions on the matter were taken by the new cabinet, headed by Juozas Tūbelis.

\section{A new law: reduced pensions}

Following the debates lasting several years, the Law on War Invalid Pensions was passed in Lithuania, coming into effect backdated to 1 January 1930. It was intended specifically for Lithuanian citizens 'who had become invalids before 16 February 1918 whilst serving in the Russian army'. The pension, ranging from 30 to 200 litas, could be paid out only if the disability reduced the ability to work by $25 \%$ or more (the 1925 law foresaw a threshold of $10 \%)$. The size of a specific pension depended on the individual's group (I for officers, and II for soldiers), and one of five categories that were based on the percentage of the incapacity to work. The highest pension of 200 litas could be allocated to a former officer who was completely incapable of working, and required constant assistance from another person, while the lowest pension of 30 litas could go to a soldier deemed $25 \%$ to $49 \%$ incapable of working. ${ }^{74}$ The pensions payment procedure was amended in $1935 .{ }^{75}$ The rules for the implementation of the law were also confirmed at the same time. ${ }^{76}$

There were clear arguments for accepting this law. The situation regarding Russian army Great War invalid pensions was considered unacceptable, as it was calculated that in 1930, 241 individuals were

${ }^{72}$ List of requests for pensions made by Russian army war invalids that was handed back to the MOD. 2 May 1930, LCVA, f. 384, ap. 5, b. 5, 1. 176-183.

${ }^{73}$ Orders given to the army, 31 August 1939, LCVA, f. 384, ap. 5, b. 47, 1. 14.

74 'Karo invalidų pensijų ịstatymas', Vyriausybès žinios, 321 (1930), pp. 18-19.

75 'Karo invalidų pensijų i̦statymo pakeitimas', Vyriausybès žinios, 490 (1935), p. 7.

76 'Karo invalidų pensijų įstatymui vykdyti taisyklès', Vyriausybès žinios, 507 (1935), p. 3; 'Karo invalidų pensijų įstatymui vykdyti taisyklių pakeitimas', Vyriausybès žinios, 659 (1939), p. 575. 
eligible for pensions based on three different procedures; however, another 1,000 had submitted applications, but had received nothing. Of the 1,240 individuals who had submitted requests, around 200 were considered less than $25 \%$ incapable of working, so according to the new law, they were not eligible for the pension. The Ministry of Defence needed 198,900 litas a year to cover the 241 pensions mentioned above. By reducing the pensions for this group by around $50 \%$ to $60 \%$, compared to Lithuanian army war invalids, and granting pensions to an additional 800 individuals, it was hoped that the financial burden would only increase by around 500,000 litas. So in total, the ministry would need around 652,000 litas per year in order to pay out Russian army Great War invalid pensions. ${ }^{77}$

Data from January 1931 gives clear proof of how the provision of pensions for Russian army Great War invalids after the passing of the new law changed, compared to Lithuanian army war invalids.

Table No 1. Provision of pensions to war invalids in Lithuania in January 1931 by the Ministry of Defence ${ }^{78}$

\begin{tabular}{|l|c|c|c|c|}
\hline \multirow{2}{*}{} & \multicolumn{2}{|c|}{ Officers } & \multicolumn{2}{c|}{ Soldiers } \\
\cline { 2 - 5 } & $\begin{array}{c}\text { Lithuanian } \\
\text { army }\end{array}$ & $\begin{array}{c}\text { Russian } \\
\text { army }\end{array}$ & $\begin{array}{c}\text { Lithuanian } \\
\text { army }\end{array}$ & $\begin{array}{c}\text { Russian } \\
\text { army }\end{array}$ \\
\hline $\begin{array}{l}\text { Number of invalids receiving } \\
\text { pensions (number of registered } \\
\text { invalids) }\end{array}$ & 20 & 11 & $218(236)$ & 584 \\
Monthly sum allocated for & 6,861 & 1,190 & 21,714 & 24,541 \\
pensions (Lt) & & & & \\
Pension amount (Lt) & $94-676$ & $60-200$ & $45-295$ & $30-136$ \\
Average pension amount (Lt) & 343,05 & 108,18 & 99,15 & 42,02 \\
Average incapacity to work (\%) & 74 & 62.73 & 51.61 & 50.6 \\
'Cost' of 1\% incapacity to work (Lt) & 4.64 & 1.72 & 1.93 & 0.83 \\
\hline
\end{tabular}

It turns out that in one month in 1931, the Ministry of Defence allocated money for 833 war invalid pensions that 'cost' no less

${ }^{77}$ Explanatory note for the law on Russian army war invalid pensions (1930), LCVA, f. 384, ap. 5, b. 11, 1. 42.

${ }^{78}$ Sources: list of Lithuanian army officer invalid pensions, 24 February 1931. LCVA, f. 384, ap. 5, b. 19, 1. 18-19; list of Russian army officer invalid pensions, 24 February 1931, ibid., 1. 20-20v; list of Lithuanian soldier invalid pensions, 24 February 1931, ibid., 1. 21-25; list of Russian war invalid soldiers receiving pensions, 24 February 1931, ibid., 1. 27-37. 
than 54,306 litas (i.e., 651,672 litas per year). Of these, 238 were for Lithuanian army invalids (28.57\%), and 595 were for Russian army war invalids (71.43\%). Regardless of this ratio, the money was clearly allocated in favour of Lithuanian army war invalids. They received $52.62 \%$ (or 28,575 litas per month, 342,900 litas per year), while First World War invalids received 47.38\% (25,731 litas per month, or 308,772 litas per year).

This trend persisted in later years as well, when the total number of war invalids increased. According to data from 1 November 1936, pensions were paid out to 406 Lithuanian army war invalids, and to 822 Russian army war invalids. Another 176 individuals were Lithuanian army war invalids who were $10 \%$ to $24 \%$ incapable of working, and so received one-off benefits; there were 635 such Russian army war invalids, yet they received neither pensions nor benefits. ${ }^{79}$ So, over five years (from 1931 to 1936), the number of invalid pension recipients grew by $47.72 \%$ (395 individuals) to 1,228 individuals. However, the number of Lithuanian army war invalids who received government pensions grew at almost double that rate during this time $(70.59 \%)$, compared to Russian army Great War invalids $(38.15 \%)$.

Understandably, when the 1930 law was passed, government bodies highlighted the positive aspects of this change. The press wrote that each year the government had to allocate around 500,000 litas to pay out Russian army Great War invalid pensions. The head of the Pensions Department, Lieutenant Colonel Juozas Katinskas (a First World War veteran who had served in the Red Army and returned to Lithuania in 1921), urged that the fact should be taken into consideration that there were many such invalids, and their pensions would require a significant sum of money. War invalids had to be aware of this, and appreciate 'every litas of their pension'. ${ }^{80}$ However, the sum that Katinskas indicated was in fact almost double the amount calculated based on data from 1931. This can be seen as an attempt to highlight the extent of the Lithuanian government's obligations to Russian army Great War invalids.

Great War invalids were naturally not very pleased at receiving pensions that were two or three times lower than those of Lithuanian

${ }^{79}$ Note from the MOD Pensions Department, 7 November 1936, LCVA, f. 384, ap. 5 , b. $32,1.234$.

${ }^{80}$ J. Katinskas, 'Tarnavusių rusų kariuomeneje invalidų pensijos', Lietuvos karo invalidy s-gos kalendorius 1932 m. (Kaunas, 1932), p. 36. 
army war invalids. The War Invalids Union appealed to the Ministry of Defence to increase pensions in 1931. It received the following response: 'Due to the general economic situation in the state, it is not possible to increase pensions for Russian army invalids at the present time. ${ }^{81}$ Russian army war invalids appealed to the Lithuanian government again in 1937, asking for their pension and social welfare levels to be equal to those of Lithuanian army war invalids. In their memorandum, they expressed their anger over the fact that, despite being Lithuanians, they were called 'Russian war invalids' everywhere, even though army officers 'or professors, lawyers, procurators' who had gone over to the Lithuanian army after their Russian military service 'unfortunately, were not called Russians'. The signatories to this document exclaimed:

We were fated to be the first to spill our blood in defending Lithuanian soil when the Great or World War arose. We were called up by the Russian army, and we were ordered to defend our country from the enemy. Some insist that we were defending the Russians' land. No. That is a lie. We were defending our Holy Lithuania, our homeland, our land, our parents and wives, brothers and children from the enemy, who struck us, forcing us to withdraw from the armed front lines to the depths of Russia to cure our wounds [...] But from the blood we let, from our wounds and our moaning in suffering, all states started to falter and sway, revolutions broke out, and our brothers, children, Lithuanians, started to gather from everywhere in Lithuania, and to seek revenge against the enemy, organising our brotherly friends, grabbing our discarded weapons and letting their blood follow in our bloody footsteps, and so, their bravery and heroic courage proved to be too great for the weakened enemy, and they cleared our land of the occupiers. ${ }^{82}$

Great War invalids in Lithuania complained about their difficult financial situation, and were surprised that the government had to pass a separate law for just a couple of hundred invalids in 1930. Veterans who had been disabled through their service in the Russian army during the Great War clearly understood that they were being set apart as a 'different' group by this kind of law, distinguished from other war invalids who, like them, had defended their Homeland Lithuania not just in the First World War, but in the Wars of Independence that followed. ${ }^{83}$ This new wave of demands coincided with the beginnings of the movement of First World War soldiers

${ }^{81}$ Note from the MOD to the chairman of the Committee for War Invalids, 16 June 1931, LCVA, f. 384, ap. 5, b. 18, 1. 4.

${ }^{82}$ Memorandum to the Cabinet of Ministers, 13 April 1937, from Lithuanian World War invalids, LCVA, f. 384, ap. 5, b. 37, 1. 29-29v.

${ }^{83}$ Ibid. 
(1937) who had served in Lithuanian national units within the Russian army. ${ }^{84}$

In addition to all of this, I have to add that in Lithuania, unlike in other countries, the question of social welfare for widows and other family members of soldiers in the Russian army who had lost their main breadwinner was not resolved. One-off benefits for families of soldiers in the Lithuanian army who had died in service were legalised in a law that was passed in $1919 .{ }^{85}$ In later years, social guarantees and allowances and pensions for the families of sacrificed soldiers were further detailed and extended. ${ }^{86}$ However, in Lithuania, no social guarantees or benefits were envisaged for families of the former Russian army soldiers who had become invalids, or widows and orphans of soldiers killed in the Great War, ${ }^{87}$ neither up to the law of 1930, nor afterwards. Incidentally, the Law on Soldiers' Pensions of 1925 did in theory foresee the provision of pensions for 'war invalids, and on their deaths, for their families'. However, this condition only applied in cases where a war invalid had died whose incapacity to work had already been determined by Lithuanian institutions. The majority of Lithuanian citizens who had lost their Russian army soldier-breadwinner in the Great War could not expect any support from the Lithuanian government. One example illustrates the social problems that arose as a result, and the reaction. In 1929, Marijona Gedrimiene from Palanga appealed to the Ministry of Defence, claiming that her son, an officer in the Russian army, had been killed in Mariupol (Ukraine) in 1918. Stating her significant age and difficult financial situation, the woman asked

${ }^{84}$ During 1917, several national Lithuanian soldiers' units formed in the Imperial Russian army. In total, there were around 3,000 men. They did not manage to reach Lithuania as an organised group, but the majority formed the core of the Lithuanian army that was just being established. In 1937, to mark the 20th anniversary of the creation of Lithuanian national units in Russia, the Lithuanian Soldiers' Movement Congress took place, where a Union of Army Founders was formed to gather these men. For more, see: A. Jurevičiūtè, 'Kariuomenès pirmūnų sajungos ịkūrimas veikla 1937-1940 metais', in: Lietuvos istorijos studijos, 19 (2007), pp. 80-99; eadem, Buvusiu kariu organizacijos, pp. 247-260; V. Lesčius, Lietuvos kariuomene 1918-1920 (Vilnius, 1998), pp. 17-59.

85 'İstatymas apie algas ir pašalpas kariškiams ir jų šeimynoms', Vyriausybès žinios, 7 (1919), p. 7.

86 'Netekusiems sveikatos kariams, jų šeimoms o taip pat žuvusiųjų karių šeimoms pensijų i̇statymas', Vyriausybès žinios, 104 (1922), pp. 6-7; 'Karių pensijų ìstatymas', Vyriausybès žinios, 201 (1925), pp. 1-4.

87 'Karo invalidų pensijų įstatymas', Vyriausybès žinios, 321 (1930), pp. 18-19. 
to be given 'at least the smallest means of support to maintain her in her old age' ${ }^{88}$ But all the ministry could reply was that, based on the law, she was not eligible for a pension, because her son had died while serving in the Russian army. The woman was told to enquire about land and firewood at the district land supervisor and the Ministry of Internal Affairs ... ${ }^{89}$

\section{Conclusions}

In Lithuania in the interwar years, the process of granting pensions to Russian army veterans injured in the First World War, as we have seen, can be divided into three periods. In the first period, up to 1926, these First World War invalids' pensions were to be equal to Lithuanian army war invalid pensions. In the second period, 1926 to 1929 , a strange situation unfolded, whereby pension allocation procedures and their amounts were legally equal for Lithuanian and Russian army war invalids, but in practice different procedures were applied. This inequality discriminated against and angered Great War invalids. The third period began in 1930, when a law was passed and started to apply to a very small group of war invalids (soldiers in the former Imperial Russian army). Its introduction, we can say, only deepened the discriminatory trends that had become evident in 1926, and prompted Great War Russian army invalids who lived in Lithuania to continue fighting for their rights and moral acknowledgement of their sacrifice.

When discussing the question of providing Russian army Great War invalids with pensions, two cardinally opposing assessments were expressed in interwar Lithuania. One group, consisting of First World War veterans and invalids, claimed that whilst serving in the Russian army, they had fought in the Great War for their Homeland Lithuania, defending its population. In their view, it was only the Great War and their struggle that had created the conditions for the Lithuanian state to be re-created. They saw the Wars of Independence that followed as a continuation of the First World War, so the Lithuanian army soldiers were simply continuing the battle they had begun. The other group asserted that it was wrong

${ }^{88}$ Letter from Marijona Gedrimiene to the MOD, dated 20 April 1929, LCVA, f. 384 , ap. 5 , b. $10,1.167$.

${ }^{89}$ Note from the MOD dated 4 July 1929, ibid., 1. 166. 
to equate Russian army Great War invalids and those invalided in the struggle for Lithuanian independence. This group did not view serving in the Imperial Russian army as defending Lithuania. In this way, they basically did not recognise the importance of the First World War to the reinstatement of Lithuania's statehood.

The general political situation in Lithuania was very important in terms of the relationship between these two approaches. During the period of parliamentary democracy, Great War veterans could defend their interests in the Seimas, which was a kind of tribune in which they could spread their concept of fighting in the Great War as the initial battle in the road towards Lithuania's freedom. After the coup of 1926, they lost this tribune, while the realisation of the progress they had made in 1925-1926 was blocked by the new government. The effective defence of the interests of war invalids as one of the groups that experienced the First World War was possible only under the conditions of a pluralist democracy. Given the conditions of the growing stronghold of authoritarianism in Lithuania after 1926, the lobbying of this group encountered numerous hurdles. Even after the law of 1930 was passed, Great War invalids still did not believe that their struggle for the same social guarantees as Lithuanian army war invalids was over. Clear demands along these lines started being expressed again in the second half of the 1930s. This shows that Russian army Great War invalids did not lose their hope that their contribution would be recognised in Lithuania, and that their position in society would improve.

\section{Author Details}

Vytautas Jokubauskas is a senior research fellow at Klaipeda University's Institute of Baltic Region History and Archaeology.

Address: Institute of Baltic Region History and Archaeology, Klaipèda University, 84 Herkaus Manto St, Klaipeda LT-92294, Lithuania

E-mail: pilsotas@yahoo.com

\section{Bibliography}

BYLA, [J.] 'Karių pensijų įstatymas', in: Kardas, 16 (1925), pp. 1-4.

BUKEVIČIUS, 'Karo invalidams šelpti komiteto dešimties metų veikimo apžvalga (1921-1931m.)', in: Mūsų žinynas, vol. XXI, 80 (1931), pp. 410-418. 
'Duos pensijas visiems invalidams', in: Trimitas, 12 (1926), p. 356.

ESSE, L. "Nii oleme 20 aastat sunnitud olnud kiratsema omariikluse juures...' Esimese maailmasõja invaliidide toetused ja ühiskondlik positsioon 1920.-1930. aastate Eestis', in: Esimene maailmasõda ja Eesti, II, ed. T. Tannberg (Tartu, 2016), pp. 507-533.

'Iš ,Isakymų Kariuomenei“: Pensijos kariams ir žuvusiujų karių šeimoms', in: Karys, 19 (207) (1923), pp. 228-229.

'İstatymas apie algas ir pašalpas kariškiams ir jų šeimynoms', in: Vyriausybès žinios, 7 (1919), p. 7.

JUREVIČIŪTĖ, A. Buvusiu kariu organizacijos ir ju vaidmuo Lietuvos vidaus politikoje 1923-1940 m., PhD thesis (Kaunas, 2009).

JUREVIČIŪTĖ, A. 'Kariuomenès pirmūnų sajungos ịkūrimas veikla 1937-1940 metais', in: Lietuvos istorijos studijos, 19 (2007), pp. 80-99.

JUREVIČIŪTĖ, A. 'Karo invalidų organizacijos Lietuvoje 1923-1940 m.', in: Kauno istorijos metraštis, vol. VIII (2007), pp. 7-54.

JUREVIČIŪTĖ, A. 'Lietuvos kariuomenès kūrejų savanorių sajungos kūrimas', in: Karo archyvas, vol. XVI (2000), pp. 137-145.

'Kariu pensijos istatymo projektas', in: Karys, 1 (293), (1925), p. 6.

'Kariu pensijų įstatymas', in: Vyriausybès žinios, 201 (1925), pp. 1-4.

'Kariu pensiju ịstatymui vykdyti taisyklès', in: Vyriausybès žinios, 213 (1926), pp. 3-7.

'Karių pensijų įstatymui vykdyti taisyklių pataisymai', in: Vyriausybès žinios, 228 (1926), pp. 4-5.

'Karo invalidų pensijų įstatymas', in: Vyriausybès žinios, 321 (1930), pp. 18-19.

'Karo invalidų pensijų i̊statymo pakeitimas', in: Vyriausybès žinios, 490 (1935), p. 7.

'Karo invalidu pensijų ịstatymui vykdyti taisyklès', in: Vyriausybès žinios, 507 (1935), pp. 3-4.

'Karo invalidu pensijų įstatymui vykdyti taisyklių pakeitimas', in: Vyriausybès žinios, 659 (1939), p. 575.

KASPARAVIČIUS, A. 'Didysis karas (1914-1918) ir Lietuva (nereikalingi faktai ir šešèliai istorinèje atmintyje)', in: Santara, 105/106 (2014), pp. 4-21.

KATINSKAS, J. 'Tarnavusių rusų kariuomeneje invalidų pensijos', Lietuvos karo invalidu s-gos kalendorius 1932 m. (Kaunas, 1932), pp. 36-40.

'Klausimai ir atsakymai', in: Karys, 43 (283) (1924), p. 356.

'Klausimai ir atsakymai', in: Trimitas, 22 (1926), p. 728.

'Klausimai ir atsakymai', in: Trimitas, 14 (1926), p. 472.

LESČIUS, V. Lietuvos kariuomene 1918-1920 (Vilnius, 1998).

'Lietuvių Vokiečių konferencija', in: Karys, 45 (285), (1924), p. 371.

'Lietuvos gyvenimas. Ministeriu Kabinetas', in: Karys, 18 (414), (1927), p. 170.

'Lietuvos gyvenimas. Vyriausybès darbai', in: Karys, 14-15 (358-359), (1926), p. 120. 
Lietuvos gyventojai. Pirmojo 1923 m. rugsejo 17 d. visuotinio gyventojų surašymo duomenys (Kaunas, 1923).

'Netekusiems sveikatos kariams, jų šeimoms o taip pat žuvusiųuų karių šeimoms pensijų įstatymas', in: Vyriausybès žinios, 104 (1922), pp. 6-7.

'Pensijos tarnavusiems rusų kariuomenejj', in: Trimitas, 11 (1928), p. 356.

SAFRONOVAS, V. 'Didžiojo karo sureikšminimo Rytų Prūsijoje ir Klaipėdos krašte prielaidos: nuostolių kompensavimo klausimas,' in: Lietuvos istorijos metraštis, 2017/1 (2017).

SAFRONOVAS, V. 'Pirmojo pasaulinio karo atminimas Lietuvoje ir Rytų Prūsijoje: naujų tyrimų pradžia', in: Lituanistica, vol. 61(3) (2015), pp. 149-159.

V.A. 'Seimas', in: Trimitas, 25 (1925), pp. 820-821.

VITKAUSKAS, V. Raštai (Vilnius, 1988).

\section{CARAS PENSIJŲ NEBŪTŲ ATĖMĘS: \\ KOMPENSACIJOS RUSIJOS KARIUOMENĖS PIRMOJO PASAULINIO KARO INVALIDAMS TARPUKARIO LIETUVOJE ${ }^{1}$}

Santrauka

\section{VYTAUTAS JOKUBAUSKAS}

Straipsnyje analizuojamas Didžiojo karo invalidų aprūpinimas Lietuvoje - Rusijos imperijos kariuomenèje per Pirmajị pasaulinị karą suluošintų karių pastangos siekiant socialinių garantijų (pensijų) ir Lietuvos teisès aktų kismas reaguojant $\mathfrak{i}$ teisètus jų lūkesčius.

Didžiojo karo invalidų, tapusių Lietuvos Respublikos piliečiais, socialiniame aprūpinime galima išskirti tris etapus: a) iki 1925-1926 m., b) 1926-1929 m. ir c) po $1930 \mathrm{~m}$. Pirmojo pasaulinio karo Rusijos kariuomenès invalidų aprūpinimas Lietuvoje buvo nuolat vertinamas pagal kompensacijas suluošintiesiems Lietuvos Nepriklausomybės karuose, bet pensijų dydžių šioms dviem grupėms sulyginti nepavyko, nors 1925-1926 m. buvo pasiekta, kad Rusijos kariuomenès Didžiojo karo invalidų ir Lietuvos kariuomenès karo invalidų pensijos būtų lygios. Vis dèlto 1926-1929 m. susiklostè situacija, kai nepaisant to, kad pensijų skyrimo procedūros ir jų dydžiai Lietuvos ir Rusijos kariuomenių karo invalidams teisiškai buvo suvienodinti, praktikoje taikyta skirtinga tvarka. Diskriminuojamus Didžiojo karo invalidus tai piktino. $1930 \mathrm{~m}$. buvo priimtas ir pradètas taikyti siaurai karo invalidų grupei (buvusiems Rusijos imperijos kariams) skirtas įstatymas, tačiau jo taikymas, galima sakyti, tik ịtvirtino $1926 \mathrm{~m}$. išryškejjusias diskriminacines tendencijas ir skatino Didžiojo karo Rusijos kariuomenès invalidus, gyvenusius Lietuvoje, toliau kovoti dèl savo teisių ir aukos moralinio pripažinimo.

\footnotetext{
${ }^{1}$ Straipsnis parengtas igyvendinant Lietuvos mokslo tarybos finansuojamą mokslininkų grupių projektą „Pirmojo pasaulinio karo atminimas: Lietuvos ir Rytprūsių lyginamoji analizė (iki 1939 metų)“ (MIP-021/2015).
} 
Svarstant Didžiojo karo Rusijos kariuomenès invalidų aprūpinimą pensijomis, tarpukario Lietuvoje pasireiške du visiškai priešingi vertinimai. Viena grupe - ją sudare pirmiausia patys Pirmojo pasaulinio karo veteranai ir invalidai - teigè, kad, tarnaudami Rusijos kariuomenėje, Didžiajame kare jie kovojo už Tẻvynę Lietuvą ir gynė jos gyventojus. Jų manymu, Didysis karas ir jų kova sudarẻ sąlygas Lietuvos valstybei atsikurti. Kovas dèl Nepriklausomybès jie vertino kaip Pirmojo pasaulinio karo tąsą, tad Lietuvos kariuomenès karius jie laikẻ savo veiklos tęsejjais. Kita grupé pabrěžè, kad sulyginti Rusijos kariuomenès Didžiojo karo ir Lietuvos kariuomenès Nepriklausomybès kovų invalidus būtų neteisinga. Tarnavimo Rusijos imperijos kariuomeneje jie nesuvokẻ kaip Lietuvos gynybos. Šitaip jie tarsi nepripažino ir Pirmojo pasaulinio karo svarbos Lietuvos valstybingumui atkurti.

Didelę reikšmę šių dviejų požiūrių santykiui turèjo bendra politinė padètis Lietuvoje. Parlamentinès demokratijos laikotarpiu Didžiojo karo veteranai galèjo ginti savo interesus Seime, kuris jiems tapo tribūna skleisti savajai sampratai apie kovą Didžiajame kare kaip pirminị kovos dèl Lietuvos laisvès etapą. Po 1926 m. valstybės perversmo šioji tribūna buvo prarasta, o iškovojimų, kuriuos pavyko pasiekti 1925-1926 m., vykdymą naujoji valdžia ėmè blokuoti. Karo invalidų, kaip vienos iš Pirmojo pasaulinio karo patirčių grupès, efektyvi veikla ginant savo interesus buvo imanoma tik pliuralistinès demokratijos sąlygomis. Po $1926 \mathrm{~m}$. Lietuvoje ịsigalint autoritarizmui, lobistinè minètosios grupès veikla patyre sunkumų. Vis dėlto Didžiojo karo invalidai ir prièmus 1930 m. ịstatymą dar nemanè, kad jų kova dèl socialinių garantijų sulyginimo su Lietuvos kariuomenès karo invalidais baigta. Aiškūs reikalavimai, nukreipti šia linkme, vèl ėmè reikštis XX a. 4-ojo dešimtmečio antroje pusėje. Tai rodo, kad Rusijos kariuomenès Didžiojo karo invalidai nenustojo vilties, kad jų indèlis Lietuvoje bus deramai ịvertintas, o socialinè padètis pagerinta. 